\title{
Range-wide status and conservation of the goliath grouper Epinephelus itajara: Introduction
}

\author{
Kevin L. Rhodes ${ }^{1, *}$, Rachel T. Graham ${ }^{2, * *}$ \\ ${ }^{1}$ The University of Hawaii at Hilo, 200 W. Kawili St., Hilo, Hawaii 97620, USA \\ ${ }^{2}$ Wildlife Conservation Society, P.O. Box 37, Punta Gorda, Belize
}

\begin{abstract}
The goliath grouper is Critically Endangered (CR A2d) throughout its range and in need of immediate management where it is lacking and continued management where it exists. A special symposium was held in November 2007 at the 60th Annual Meeting of the Gulf and Caribbean Fisheries Institute to share recent research findings and establish a regional research, conservation and management network to improve the species' status. Eleven contributions were chosen from the symposium to help enrich our understanding of the species' management needs within a biological, ecological, phylogeographic and fisheries context. One contribution provides important information on the human health effects of goliath grouper consumption.
\end{abstract}

KEY WORDS: Epinephelidae $\cdot$ Gulf and Caribbean Fisheries Institute $\cdot$ Overfishing $\cdot$ Management

The goliath grouper Epinephelus itajara, Lichtenstein 1822 (formerly jewfish) is a widely distributed species that is often a favored target of recreational, small-scale commercial and subsistence fishers (Heemstra \& Randall 1993). Like many of its congeners, it has a host of life history traits that increase its vulnerability to overfishing and population decline: strong site attachment during various life history stages, the formation of small, seasonally brief spawning aggregations, long life, late maturation and slow growth (Sadovy \& Eklund 1999). As a consequence of spawning aggregation fishing and loss of critical habitat, reductions in population abundance have been widely reported and the species is now listed as Critically Endangered (CR A2d) by the International Union for Conservation of Nature (IUCN 2008). As a result of these declines and an obvious need for management improvement, a special symposium was held in Punta Cana, Dominican Republic, on 7 November 2007 (60th Annual Meeting of the Gulf and Caribbean Fisheries Institute) to address these concerns, to present findings of recent research, and to provide direction for future research and conservation action. This Theme Section contains selected contributions from the symposium to improve our understanding of goliath grouper biology and life history, and enhance our ability to effectively manage and conserve the species.
Technical approaches to monitoring goliath grouper. A number of challenges exist in monitoring goliath grouper populations and documenting critical life history events. For example, juveniles typically inhabit murky, turbid waters of inshore mangrove habitats, and adults are often widely dispersed in deepwater offshore reefs where they are thought to spawn. Contributions to this Theme Section of Endangered Species Research report on the use of non-lethal underwater acoustic technology or combined sonaracoustic methods to help overcome these challenges. Pina-Amargós \& González-Sansón (2009, this Theme Section) utilize conventional tagging to show strong site attachment by adults during non-reproductive periods and relatively long-distance movement within reproductive periods, which assist in the design of biologically meaningful marine protected areas (MPAs) for the species. Mann et al. (2009, this Theme Section) combine acoustic telemetry with passive acoustic sound recording to gain insight into possible spawning times, sites and behaviors and allow large-scale temporal and spatial monitoring to be achieved. Frias-Torres \& Luo (2009, this Theme Section) present findings from a test of a dual frequency identification sonar (DIDSON) acoustic camera, enhancing the ability to detect juveniles in habitats typically inaccessible to 
divers during visual census. These combined methods provide technical alternatives to assist scientists in understanding critical life history events and habitat associations for improved management.

Non-lethal age and growth determinations. Assessments of many life history components of endangered species are challenged by the need to sample nondestructively, while also obtaining sufficient sample sizes. Some assessments, such as age and growth, typically require relatively large numbers of samples, which for endangered species is problematic. For example, previous studies of goliath grouper age and growth relied on destructively sampling large numbers of individuals (e.g. 384 individuals, Bullock et al. 1992), a procedure which is no longer acceptable. Using nonlethal aging techniques successfully employed with other marine teleosts, Brusher \& Schull (2009, this Theme Section) and Murie et al. (2009, this Theme Section) sampled and aged goliath grouper across a range of size and age classes. Their comparisons of standard lethal aging techniques with non-lethal aging techniques demonstrate the utility of non-destructive alternatives and allow further non-lethal assessments of population demography and responses to fishing and management.

Historical and contemporary monitoring and assessment of goliath grouper fisheries. Goliath grouper is known or perceived as overfished throughout its range; however, few countries have adequately documented these declines or instituted management responses. Although fisheries-induced declines have likely been accumulating for decades, documentation of these declines are typically over much shorter time scales or nonexistence. This Theme Section includes assessments using both traditional and non-traditional fisheries assessments to illustrate historic long-term declines and some evidence of recent recovery of a goliath grouper population following protection. Using historical photos from the Florida recreational fishery, McClenachan (2009, this Theme Section) documents decadal declines in goliath grouper populations prior to a 1990 catch moratorium in the southern USA which was intended as a means of restoring the species. Using more traditional methods, Cass-Calay \& Schmidt (2009, this Theme Section) performed longterm creel survey analyses based on the Everglades National Park recreational fishery to examine recovery of goliath grouper following the moratorium. Graham et al. (2009, this Theme Section) use more contemporary traditional fisheries-dependent assessments of the southern Belize commercial fishery to highlight a fishery reliant on juveniles and document perceived declines in adult populations and spawning aggregations. These combined studies show the need for immediate management where it is currently lacking and continued management where it already exists. Cass-Calay \& Schmidt (2009) clearly demonstrate that population restoration following severe declines, such as those experienced in the USA, will likely take decades.

Human health concerns of goliath grouper consumption. Human health concerns regarding the consumption of top predators are well documented, particularly for pelagic fishes (e.g. Thynnus spp., Xiphias gladius). Less is known, however, about the health effects of consuming top predators associated with reef environments. Evers et al. (2009, this Theme Section) provide convincing and disconcerting evidence of negative health impacts from consumption of goliath grouper across a broad size range. These findings suggest that caution should be exercised among high-risk consumers when considering consumption of goliath grouper and also highlight the need for additional studies on the health impacts of consuming other reefassociated top predators.

Phylogeographic relationships of goliath grouper. Effective management of any species requires a clear understanding of its geographic and genetic affinities. During a recent genetic assessment of goliath grouper, Craig et al. (2009, this Theme Section) not only defined the phylogeographic boundaries of the species, but were able to determine the existence of a sister species in the central eastern Pacific. Genetic divisions within the western Atlantic also point to the need for regionalized management. These findings are critical to our ability to properly conserve these 2 rare species and suggest immediate and enhanced management for both goliath grouper populations to prevent extinction.

Larval descriptions of goliath grouper. Although the goliath grouper has been an important component of commercial and recreational fisheries for generations, many aspects of its biology and life history are still undescribed. Lara et al. (2009, this Theme Section) provide the first descriptions of the early life history stages of goliath grouper and give information on spawning times and larval duration, suggesting the potential for relatively long delays in settlement following hatching.

These combined findings show that the status of goliath grouper within its distributional range is mixed, and highlight the need for improved management where measures are already in place and immediate implementation where they are lacking. Using this new information and the technical applications provided in this Theme Section, we are guardedly optimistic that improvements to regional management can be made to allow population persistence to be achieved, and realistic in suggesting that a continued lack of management will result in the species' demise in much of its range. 
Acknowledgements. We thank the organizers of the 60th Gulf and Caribbean Fisheries Institute (GCFI) for providing a venue to discuss the conservation needs and scientific findings for goliath grouper. We also thank all the contributors who presented their findings both here and during the GCFI Symposium. Primary funding for the Symposium was kindly contributed by the Wildlife Conservation Society, the Summit Foundation, the Ocean Foundation and the National Oceanographic and Atmospheric Administration's National Marine Fisheries Service Southeast Fisheries Science Center.

\section{LITERATURE CITED}

Brusher JH, Schull J (2009) Non-lethal age determination for juvenile goliath grouper Epinephelus itajara from southwest Florida. Endang Species Res 7:205-212

Bullock LH, Murphy MD, Godcharles MF, Mithell ME (1992) Age, growth and reproduction of jewfish, Epinephelus itajara in the eastern Gulf of Mexico. Fish Bull (Wash DC) 90: 243-249

Cass-Calay SL, Schmidt TW (2009) Monitoring changes in the catch rates and abundance of juvenile goliath grouper using the ENP creel survey, 1973-2006. Endang Species Res 7:183-193

Craig, MT, Graham RT, Torres RA, Hyde JR and others (2009) How many species of goliath grouper are there? Cryptic genetic divergence in a threatened marine fish and the resurrection of a geopolitical species. Endang Species Res 7:167-174

Evers DC, Graham RT, Perkins CR, Michener R, Divoll T (2009) Mercury concentrations in the goliath grouper of Belize: an anthropogenic stressor of concern. Endang Species Res 7:249-256

Frias-Torres S, Luo J (2009) Using dual-frequency sonar to detect juvenile goliath grouper Epinephelus itajara in mangrove habitat. Endang Species Res 7:237-242
Graham RT, Rhodes KL, Castellanos D (2009) Characterization of the goliath grouper Epinephelus itajara (Lichtenstein, 1822) fishery of southern Belize for conservation planning. Endang Species Res 7:195-204

Heemstra PC, Randall JE (1993) FAO species catalog: groupers of the world (family Serranidae, subfamily Epinephelinae). An annotated and illustrated catalogue of the grouper, rockcod, hind, coral grouper and lyretail species known to date. FAO Fisheries Synopsis 16(125)

IUCN (International Union for Conservation of Nature) (2008) IUCN Red List of Endangered Species. Www. redlist.org

> Lara MR, Schull J, Jones DL, Allman R (2009) Early life history stages of goliath grouper Epinephelus itajara (Pisces: Epinephelidae) from Ten Thousand Islands, Florida. Endang Species Res 7:221-228

> Mann DA, Locascio JV, Coleman FC, Koenig CC (2009) Goliath grouper Epinephelus itajara sound production and movement patterns on aggregation sites. Endang Species Res 7:229-236

McClenachan L (2009) Historical declines of goliath grouper populations in South Florida, USA. Endang Species Res 7: 175-181

Murie DJ, Parkyn DC, Koenig CC, Coleman FC, Schull J, Frias-Torres S (2009) Evaluation of finrays as a non-lethal ageing method for protected goliath grouper Epinephelus itajara. Endang Species Res 7:213-220

Pina-Amargós F, González-Sansón G (2009) Movement patterns of goliath grouper Epinephelus itajara around southeast Cuba: implications for conservation. Endang Species Res 7:243-247

Sadovy Y, Eklund AM (1999) Synopsis of biological data on the Nassau grouper, Epinephelus striatus (Bloch, 1792), and the jewfish, E. itajara (Lichenstein, 1822). NOAA Tech Rep NMFS 146, US Dept. of Commerce, Seattle, WA 